\title{
ОСОБЛИВОСТІ ЗМІН МІКРОЦИРКУЛЯТОРНОЇ ЛАНКИ СИСТЕМИ КРОВООБІГУ ПРИ МЕТАБОЛІЧНОМУ СИНДРОМІ В ЗАЛЕЖНОСТІ ВІД ПОЄДНАННЯ КІЛЬКОСТІ ЙОГО ОЗНАК У ОСІБ ПОХИЛОГО ВІКУ*
}

\author{
Коркушко О. В., Ніколаев Р. С., Шатило В. Б., Чижова В. П., \\ Сафонова М. I., Самоць I. А., Дужак Г. В., Ковтонюк Т. I. \\ ДУ "Інститут геронтології іл. Д. Ф. Чеботарьова НАМН Украӥни», \\ м. Київ, Украӥна \\ vchizhova@ukr.net
}

Метаболічний синдром (МC) - не лише потенційний маркер підвищеного ризику розвитку цукрового діабету (ЦД) 2 типу, але й фактор, що сприяе розвитку атеротромботичних змін судин на різних рівнях: церебральної, кардіальної та мікроциркуляторної ланок системи кровообігу. Поширеність МС значно перевищуе поширеність ЦД. Особи з МС - це головний контингент, з якого «рекрутуються» нові хворі, які мають вперше виявлений ЦД 2 типу.

Розуміння формування патогенезу МC важливе не лише для належної клінічної практики, оскільки оріентуе лікарів різних спеціальностей на виявлення факто- рів ризику серцево-судинних захворювань, а й для розробки превентивних заходів щодо розвитку судинних ускладнень. Деякі дослідники показали, що виявлення осіб із $\mathrm{MC}$ дозволяе виявити осіб із підвищеним ризиком розвитку судинних ускладнень ішемічного інсульту або транзиторної ішемічної атаки (TIA) $[1,2]$. Інші стверджують, що $\mathrm{MC}$ може не бути предиктором повторного інсульту [3, 4]. Проте доведено, що МС асоціюеться з високим ризиком рецидиву інсульту у паціентів з перенесеним ішемічним інсультом, особливо на тлі ЦД 2 типу $[5,6]$. Отже, питання зв'язку між МC та рецидивом ішемічного інсульту (після

* Работу виконано у відділі клінічної фізіології та патології внутрішніх органів ДУ «Інститут геронтології Національної НАМН України імені Д. Ф. Чеботарьова» під керівництвом академіка Національної НАМН України, професора, д. м. н. Коркушко О. В. в рамках наукових тематик відділу: «Визначення ролі вікових особливостей толерантності до вуглеводів при старінні як передумови розвитку метаболічного синдрому» (№ держреестрації 0108U001787), «Стан мікроциркуляції, функції ендотелію та системи гемостазу у людей літнього віку з інсулінорезистентністю» (№ держреестрації 0111U001481), «Клініко-фрізіологічне обгрунтування застосування гіпоксичних тренувань для корекції порушень вуглеводного обміну у людей літнього віку з синдромом інсулінорезистентості» (№ держреестрації 0114U002251).

Установою, що фінансуе дослідження, е НАМН України.

Автори гарантують повну відповідальність за все, що опубліковано в статті.

Автори гарантують відсутність конфлікту інтересів і власної фінансової зацікавленості при виконанні роботи та написанні статті.

Рукопис надійшов до редакції 4.08.2020. 
інсульту або TIA) залишається відкритим та спірним. Проте, замало уваги приділяється станам, що передують розвитку ЦД 2 типу - предіабетичним (ізольована порушена глікемія натще (ПГН), ізольована порушена толерантність до глюкози (ПТГ) та їх поєднання ПГН + ПТГ).
Нами проведено дослідження, в яке включені особи з МС, які мали предіабетичні порушення вуглеводного обміну (ППВО) та які не мали предіабетичні порушення вуглеводного обміну з летою з'ясування ролі ППВО в розвитку змін мікроциркуляції на рівні судин бульбарної кон'юнктиви.

\section{МАТЕРІАЛИ ТА МЕТОДИ}

Включені в дослідження особи підписали інформовану згоду на участь в дослідженні (протокол № 9 від 11 червня 2013 р.), що розроблена відповідно до законодавства України і принципів Гельсінської Декларації з прав людини комісією з питань етики клінічного відділу ДУ «Інститут геронтології ім. Д. Ф. Чеботарьова Національної АМН України». Критеріями МС було обрано критерії ATP III (2003) [7].

Порушення вуглеводного обміну виявляли при проведенні стандартного глюкозо-толерантного тесту (СГТТ) за критеріями ВООЗ [8-10].

Для виключення органічної кардіальної патології, порушень ритму та провідності застосовували запис стандартної ЕКГ всім обстеженим за стандартною методикою на апараті Юкард 200 (6/12 канальний).

Вивчення стану мікроциркуляції бульбарної кон'юнктиви вивчали із застосуванням телевізійної щілинної лампи фірми «Zeiss» (Німеччина) та подальшої обробки отриманих записів у режимі стоп-кадр із морфометричною оцінкою [11].

Стан судинно-тромбоцитарного гемостазу оцінювали, вивчаючи агрегаційну активність тромбоцитів на двохканальному лазерному аналізаторі агрегації тромбоцитів 23 LA (Біола, Росія) турбудіметричним методом [12]. В’язкість крові визначали за допомогою ротаційного віскозиметра АКР-2 (Росія) при швидкостях зсуву 10-200 c-1 з розрахунком індекса деформування (співвідношенням показника в'язкості крові при швидкості зсуву $100 \mathrm{c}^{-1}$ та при швидкості зсуву $200 \mathrm{c}^{-1}$ ) та індекса агрегації еритроцитів (співвідношення показника в'язкості крові при швидкості зсуву $20 \mathrm{c}^{-1}$ та в'язкості крові при швидкості зсуву $100 \mathrm{c}^{-1}$ ).

Характер розподілу отриманих варіаційних рядів було перевірено за допомогою критерію Shapiro-Wilk W (Шапиро-Вилка W тест), який засвідчив нормальний (гаусівський) характер розподілу даних. Відтак, при виконанні статистичної обробки отриманих даних було застосовано наступні методи: розрахунок середнього арифметичного та його середньої похибки ( $\mathrm{M} \pm \mathrm{M})$; проведення оцінки вірогідності різниці отриманих результатів у порівнюваних групах за допомогою критерію Стьюдента. Для порівняння частоти зустрічаємості якісних показників застосовували критерій х2 Пірсона для таблиць сполученості з поправкою Йейтса [13].

\section{РЕЗУЛЬТАТИ ТА ЇХ ОБГОВОРЕННЯ}

Проведене дослідження базуеться на результатах обстеження 142 осіб різного віку. Всі обстежені особи мали ОТ $\geq 88$ см у жінок та $\geq 102$ см у чоловіків та ще від двох до чотирьох ознак МC, що стало в основі перерозподілу їх на підгрупи з «неповним $\mathrm{MC}$ » та «повним МC» середнього та похилого віку (табл. 1).

Групи між собою значущо не різнилися за гендерним складом, проте доля осіб жіночого віку істотно зростала у віці 60 років та старше (табл. 1). За частотою кожного з компонентів МС між групами була істотна відмінність, крім критерію абдомінального ожиріння. Також групи відрізнялися за числом критеріїв МС, що було в основі розподілу. Всім включеним в дослідження особам було проведено СГТТ (табл. 2).

При зростанні кількості ознак МC у середньому віці не виявлено різниці $(p>0,05)$ в зростанні ППВО, проте в групі осіб старше 60 років із зростанням кількості ознак $\mathrm{MC}$ достовірно зростає відсоток осіб із ППВО $(p<0,01)$. 
Частота ознак MC в групах обстежених

Таблиця 1 3 ознаками MC, n = 142

\begin{tabular}{|c|c|c|c|c|}
\hline \multirow{4}{*}{ Ознаки } & \multicolumn{2}{|c|}{$\begin{array}{c}40-59 \text { років } \\
n=52 \\
\text { ч-23, ж-29 }\end{array}$} & \multicolumn{2}{|c|}{$\begin{array}{c}60 \text { років та старше } \\
\text { n }=90 \\
\text { ч- } 27, \text { ж-63 }\end{array}$} \\
\hline & \multicolumn{2}{|c|}{ Число компонентів МС } & \multicolumn{2}{|c|}{ Число компонентів МС } \\
\hline & $\begin{array}{c}1-2 \\
\mathbf{n}=33 \\
\text { ч-13, ж-20 }\end{array}$ & $\begin{array}{c}3-5 \\
\mathbf{n}=19 \\
\text { ч-10, ж-9 }\end{array}$ & $\begin{array}{c}1-2 \\
\mathrm{n}=32 \\
\text { ч-10, अ-22 }\end{array}$ & $\begin{array}{c}3-5 \\
\mathrm{n}=\mathbf{5 8} \\
\text { ч-17, ж-41 }\end{array}$ \\
\hline & абс., n (\%) & абс., n (\%) & абс., $\mathrm{n}(\%)$ & абс., $\mathrm{n}(\%)$ \\
\hline $\mathrm{OT}, \mathrm{cm}^{*}$ & $33(100)$ & $19(100)$ & $32(100)$ & $58(100)$ \\
\hline ТГ $\geq 1,7$ ммоль/л & $3(9,1)$ & $16(84,2)$ & $3(9,4)$ & $39(67,2)$ \\
\hline ХС-ЛВГ & $9(27,3)$ & $17(89,5)$ & $4(12,5)$ & $26(44,8)$ \\
\hline $\mathrm{AT} \geq 130 / 85$ мм рт ст & $7(21,2)$ & $15(78,9)$ & $4(12,5)$ & $31(53,4)$ \\
\hline $\begin{array}{c}\text { Концентрація глюкози } \\
\text { в плазмі крові } \geq 6,1 \text { ммоль/л }\end{array}$ & $4(12,1)$ & $10(52,6)$ & $2(6,25)$ & $30(51,7)$ \\
\hline
\end{tabular}

Розподіл обстежених з ознаками МС за числом компонентів МС,

Таблиця 2 віком та результатом СГТТ, $\mathrm{n}=142$

\begin{tabular}{|c|c|c|c|c|c|}
\hline Ознаки & $\begin{array}{r}40-5 \\
n-2 \\
4\end{array}$ & & $\begin{array}{r}60 \text { рокі } \\
1 \\
\text { ч-2 }\end{array}$ & $\begin{array}{l}\text { старше } \\
0 \\
-63\end{array}$ & \\
\hline & Число кол & гентів МC & Число ко & нентів МC & \\
\hline Групи & $\begin{array}{c}1-2 \\
\mathrm{n}=33 \\
\text { ч/\% } \\
13 / 20 \\
(1)\end{array}$ & $\begin{array}{c}3-5 \\
\mathrm{n}=19 \\
\text { ч/\% } \\
10 / 9 \\
(2)\end{array}$ & $\begin{array}{c}1-2 \\
\mathrm{n}=32 \\
\text { ч/ж } \\
10 / 22 \\
(3)\end{array}$ & $\begin{array}{c}3-5 \\
\mathrm{n}=58 \\
\text { ч/\% } \\
17 / 41 \\
(4)\end{array}$ & $\mathbf{p}$ \\
\hline & $\begin{array}{c}\text { абс., } \mathbf{n} \\
(\%)\end{array}$ & $\begin{array}{c}\text { абс., } \mathbf{n} \\
(\%)\end{array}$ & $\begin{array}{c}\text { абс., } \mathbf{n} \\
(\%)\end{array}$ & $\begin{array}{c}\text { абс., } \mathbf{n} \\
(\%)\end{array}$ & \\
\hline Без порушень & $24(46,2)$ & $9(17,3)$ & $22(24,4)$ & $20(22,2)$ & $\begin{array}{c}\mathrm{X}^{2}{ }_{2-1}=2,15, \mathrm{P}_{2-1}>0,05 \\
\mathrm{X}^{2}{ }_{3-4}=\mathbf{9 , 7 3}, \mathbf{P}_{3-4}<\mathbf{0 , 0 1} \\
\mathrm{X}^{2}{ }_{3-1}=\mathbf{1 1}, \mathbf{2 1}, \mathbf{P}_{3-1}<\mathbf{0 , 0 1} \\
\mathrm{X}^{2}{ }_{4-2}=1,01, \mathrm{P}_{4-2}>0,05 \\
\mathrm{X}_{2-3}^{2}=2,28, \mathrm{P}_{4-2}>0,05\end{array}$ \\
\hline $\begin{array}{c}\text { Порушення } \\
\text { глікемії натще } \\
\text { (ПГН) }\end{array}$ & $3(5,8)$ & $8(15,4)$ & $1(1,1)$ & $12(13,3)$ & $\begin{array}{l}\mathrm{X}^{2}{ }_{2-1}=14,60, \mathrm{P}_{2-1}<0,01 \\
\mathrm{X}^{2}{ }_{3-4}=5,15, \mathrm{P}_{3-4}<0,05 \\
\mathrm{X}^{2}{ }^{2}=12,64, \mathrm{P}_{3-1}<0,01 \\
\mathrm{X}^{2}{ }_{4-2}=4,46, \mathrm{P}_{4-2}<\mathbf{0 , 0 5} \\
\mathrm{X}^{2}{ }_{2-3}=12,46, \mathrm{P}_{4-2}<0,01\end{array}$ \\
\hline $\begin{array}{c}\text { Порушення } \\
\text { толерантності } \\
\text { до глюкози (ПТГ) }\end{array}$ & $5(9,6)$ & $0(0)$ & $8(8,9)$ & $8(8,9)$ & $\begin{array}{l}\mathrm{X}^{2}{ }_{2-1}=3,18, \mathrm{P}_{2-1}>0,05 \\
\mathrm{X}^{2}{ }^{3-4}=1,41, \mathrm{P}_{3-4}>0,05 \\
\mathrm{X}^{2}{ }_{3-1}=0,75, \mathrm{P}_{3-1}>0,05 \\
\mathrm{X}^{2}{ }_{4-2}=2,92, \mathrm{P}_{4-2}>0,05 \\
\mathbf{X}^{2}{ }_{2-3}=\mathbf{5 , 2 7}, \mathbf{P}_{4-2}<\mathbf{0 , 0 5}\end{array}$ \\
\hline $\begin{array}{c}\text { Поеднання } \\
\text { порушень }\end{array}$ & $1(1,9)$ & $2(3,8)$ & $1(1,2)$ & $18(20)$ & $\begin{array}{c}\mathrm{X}^{2}{ }_{2-1}=1,11, \mathrm{P}_{2-1}>0,05 \\
\mathrm{X}^{2}{ }_{3-4}=\mathbf{9 , 6 4}, \mathbf{P}_{3-4}<\mathbf{0 , 0 1} \\
\mathrm{X}^{2}{ }_{3-1}=0,001, \mathrm{P}_{3-1}>0,05 \\
\mathrm{X}^{2}{ }_{4-2}=3,13, \mathrm{P}_{4-2}>0,05 \\
\mathrm{X}_{2-3}^{2}=1,18, \mathrm{P}_{4-2}>0,05\end{array}$ \\
\hline
\end{tabular}


Показники мікроциркуляції бульбарної кон'юнктиви у осіб різного віку з ознаками МС за числом компонентів МС

\begin{tabular}{|c|c|c|c|c|}
\hline \multirow{3}{*}{$\underbrace{\text { Групи }}_{\text {Показники }}$} & \multirow{2}{*}{\multicolumn{2}{|c|}{$\begin{array}{c}\text { 40-59 років } \\
\text { Кількість ознак MC }\end{array}$}} & \multirow{2}{*}{\multicolumn{2}{|c|}{$\begin{array}{c}60 \text { років і старше } \\
\text { Кількість ознак МC }\end{array}$}} \\
\hline & & & & \\
\hline & $1-2$ & $3-5$ & $1-2$ & $3-5$ \\
\hline $\begin{array}{c}\text { Судинний } \\
\text { кон'юнктивальний індекс }\end{array}$ & $8,3 \pm 0,9$ & $10,0 \pm 1,2^{*}$ & $12,7 \pm 0,7^{*}$ & $12,6 \pm 0,8^{\#}$ \\
\hline $\begin{array}{c}\text { Позасудинний } \\
\text { кон' юнктивальний індекс }\end{array}$ & $0,9 \pm 0,01$ & $0,9 \pm 0,01$ & $1,0 \pm 0,01$ & $1,0 \pm 0,01$ \\
\hline $\begin{array}{l}\text { Внутрішньосудинний } \\
\text { кон'юнктивальний індекс }\end{array}$ & $2,8 \pm 0,4$ & $3,4 \pm 0,6^{*}$ & $5,3 \pm 0,6^{* *}$ & $4,8 \pm 0,4^{* \#}$ \\
\hline $\begin{array}{c}\text { Загальний } \\
\text { кон'юнктивальний індекс }\end{array}$ & $12,0 \pm 1,2$ & $14,3 \pm 1,6^{* *}$ & $18,7 \pm 0,8^{*}$ & $17,6 \pm 1,0^{*}$ \\
\hline Діаметр артеріол, мкм & $14,2 \pm 0,6$ & $13,3 \pm 1,2^{*}$ & $13,1 \pm 0,6$ & $13,5 \pm 2,7$ \\
\hline Діаметр венул, мкм & $44,9 \pm 3,4$ & $44,7 \pm 3,0$ & $51,9 \pm 3,6$ & $57,5 \pm 2,7^{*}$ \\
\hline $\mathrm{ABK}$ & $0,3 \pm 0,01$ & $0,3 \pm 0,01$ & $0,3 \pm 0,01$ & $0,2 \pm 0,01^{* \#}$ \\
\hline $\begin{array}{l}\text { Кількість функціонуючих } \\
\text { капілярів в } 1 \mathrm{mм}^{2}\end{array}$ & $10,7 \pm 0,7$ & $9,0 \pm 0,8^{*}$ & $8,3 \pm 0,3^{*}$ & $7,2 \pm 0,4^{* \#}$ \\
\hline
\end{tabular}

Прилітки:

Вірогідність різниці порівняно з групою 40-59 років з $1-2$ ознаками MC: ${ }^{*} \mathrm{p}<0,05,{ }^{* *} \mathrm{p}<0,01$. Вірогідність різниці порівняно з групою $40-59$ років з $3-5$ ознаками $\mathrm{MC}:{ }^{\#} \mathrm{p}<0,05,{ }^{\#} \mathrm{p}<0,01$. Вірогідність різниці порівняно з групою 60 років і старше з $1-2$ ознаками $\mathrm{MC}$ : ${ }^{a} \mathrm{p}<0,05$, ${ }^{\text {a a }} \mathrm{p}<0,01$.

При «повному» МС частота виявлення ППВО практично однакова $(\mathrm{p}>0,05)$ у середньому та похилому віці, структура виявлених змін змінюеться. Порушення глікемії натще як в середньому $(\mathrm{p}<0,01)$, так і в похилому віці $(\mathrm{p}<0,05)$ виявляеться частіше при «повному» МС. Порушення толерантності до глюкози $(\mathrm{p}<0,05)$ та поеднання порушень частіше $(\mathrm{p}<0,01)$ виявляеться у осіб старше 60 років навіть при наявності 1-2 ознак MC.

Проведення СГТТ у осіб з ознаками МС (табл. 2) дозволяе виявити приховані ППВО (ізольоване порушення толерантності до глюкози та поєднання порушення глікемії натще і порушення толерантності до глюкози), що дає додаткову інформацію про патофізіологічні зміни на тлі МС. Обмежившись лише визначенням концентрації глюкози натще від лікаря (дослідника) предіабетичні зміни стають прихованими.

Так, приховані ППВО при СГТТ виявляються у $15,3 \%$ осіб середнього віку та $39 \%$ осіб похилого віку. Дослідженню судинних змін на цій стадії приділяеться дуже мало уваги. Враховуючи неспецифічність судин- них змін, у осіб похилого віку все ж таки є певні ознаки, на фоні яких розвиваються і патологічні зміни - ангіопатія.

При МС у 45\% обстежених осіб старшого віку із збільшенням ознак МС (табл. 3) у всіх відділах мікроциркуляторного русла (венули, артеріоли, капіляри) виявлено посилення нерівномірності калібру судин і наявності їх звивистості (особливо венул), наявності спазму артеріол, зменшення кількості функціонуючих капілярів із безсудинними ділянками в перілімбальній зоні.

Позасудинні зміни бульбарної мікроциркуляції представлені поодинокими мікрогеморагіями (1-3\% випадків), помірно вираженим периваскулярним набряком. У ціеї когорти осіб відмічено наявність ліпідних відкладань в підслизовій оболонці бульбарної кон'юнктиви.

Перераховані вище зміни знайшли свое відображення в збільшенні показника загального кон'юнктивального індексу за рахунок судинного, позасудинного і внутрішньосудинного індексів (табл. 3).

Внутрішньосудинні зміни бульбарної мікроциркуляції превалюють у групі осіб 


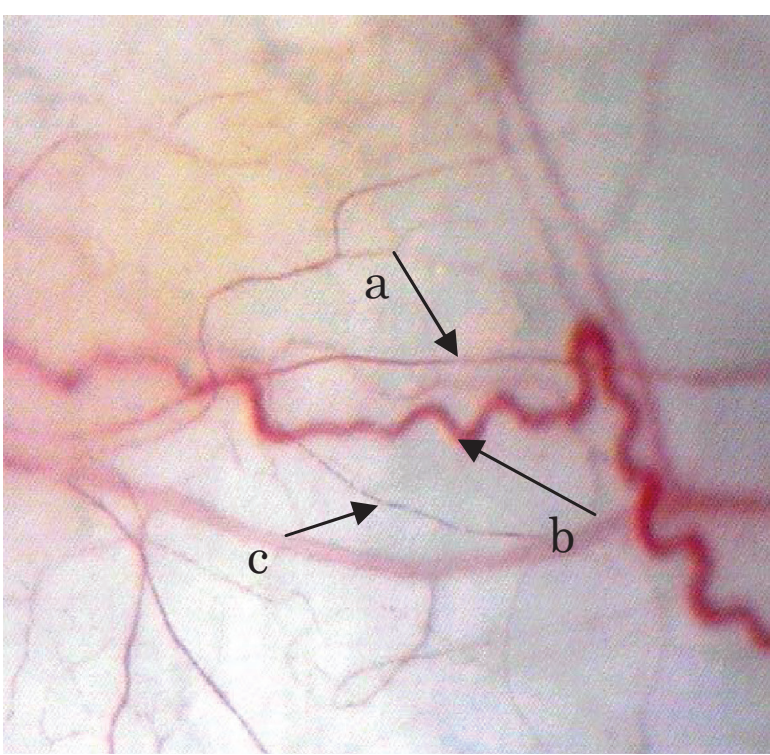

Приклад 1.

Особа середнього віку з «повним МС». М-кий, 54 роки.

Співвідношення діаметрів артеріол та відповідних венул 1:3, калібр судин нерівномірний, спазмовані артеріоли, атонічні венули, сладж-френомен в артеріолах та капілярах. Ліпідні включення.

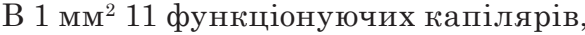
кровоплин зернистий, уповільнений. a - артеріоли, b - венули, с - капіляри.

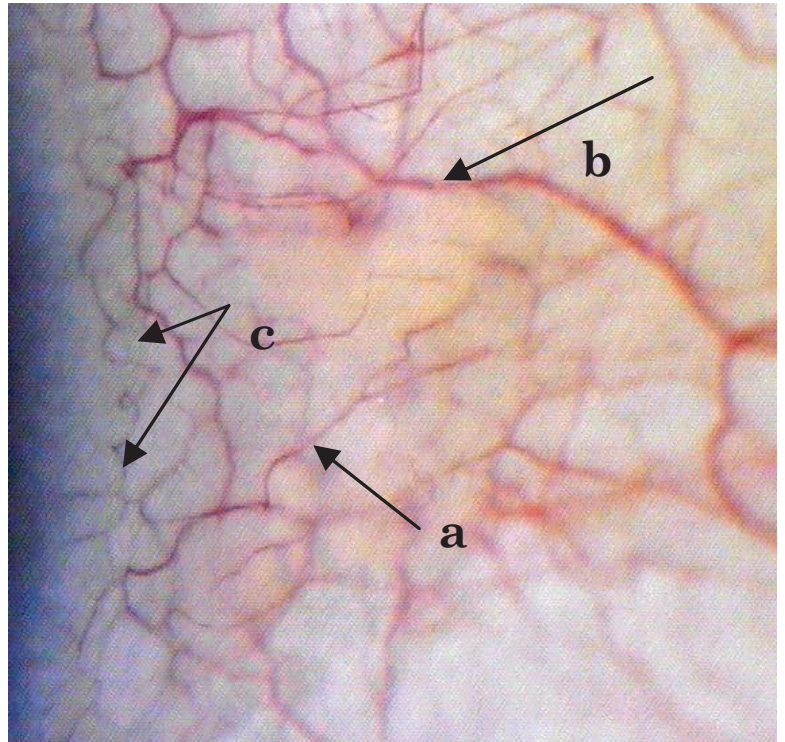

Приклад 2.

Особа похилого віку з «повним МС». К-ко, 68 років.

Співвідношення діаметрів артеріол та відповідних венул $1: 4-1: 5$, калібр судин нерівномірний, виражена сіткоподібна структура судин. В 1 мм² 10 фрункціонуючих капілярів, кровоплин гомогенно-зернистий, уповільнений, в артеріолах та капілярах спостерігається сладж-феномен. Ліпідні включення.

a - артеріоли, b — венули, с — капіляри.

Показники агрегаційної активності тромбоцитів у осіб різного віку з ознаками МС за числом компонентів МС

\begin{tabular}{c|c|c|c|c}
\hline \multirow{2}{*}{ Групи } & \multicolumn{2}{|c|}{$\mathbf{4 0 - 5 9}$ років } & \multicolumn{2}{c}{$\mathbf{6 0}$ років і старше } \\
\cline { 2 - 5 } Показники & \multicolumn{2}{|c|}{ Кількість ознак MC } & \multicolumn{2}{c}{ Кількість ознак МC } \\
\cline { 2 - 5 } & $\mathbf{1 - 2}$ & $\mathbf{3 - 5}$ & $\mathbf{1 - 2}$ & $\mathbf{3 - 5}$ \\
\hline Спонтанна агрегація, \% ОЩ & $3,1 \pm 0,9$ & $3,6 \pm 1,0^{*}$ & $3,6 \pm 0,7^{*}$ & $4,6 \pm 0,8^{*}$ \\
\hline $\begin{array}{c}\text { Адреналін-індукована } \\
\text { агрегація, \% ОЩ }\end{array}$ & $44,0 \pm 7,8$ & $47,6 \pm 11,7$ & $59,2 \pm 7,8^{*}$ & $55,4 \pm 5,8$ \\
\hline $\begin{array}{c}\text { АДФ-індукована агрегація, \% } \\
\text { ОЩ }\end{array}$ & $57,7 \pm 9,6$ & $57,6 \pm 7,2$ & $67,4 \pm 8,7$ & $69,9 \pm 7,9$ \\
\hline
\end{tabular}

Примітки:

Вірогідність різниці порівняно з групою 40-59 років з 1-2 ознаками MC: ${ }^{*} p<0,05,{ }^{* *} \mathrm{p}<0,01$. Вірогідність різниці порівняно з групою 40-59 років з 3-5 ознаками $\mathrm{MC}$ : ${ }^{\mathrm{p}}<0,05$, \# $\mathrm{p}<0,01$. Вірогідність різниці порівняно з групою 60 років і старше з $1-2$ ознаками МC: ${ }^{a} \mathrm{p}<0,05$, a a $\mathrm{p}<0,01$.

з «повним МС» літнього віку і характеризуються наявністю вираженого сладжсиндрому, який зустрічаеться в артеріолах, посткапілярних венулах і капілярах, і зумовлюе підвищення показника внутрішньосудинного індексу.

У осіб середнього віку з «повним МС» дані зміни відмічено на фоні практично збереженої архітектоніки судин із задовільною кількістю функціонуючих капілярів (приклад 1 та 2). Виявлені зміни мікроциркуляції, імовірно, нашаровуються на вже існуючи вікові і можуть бути фоном для розвитку мікроангіопатії.

При «повному МС» наявним е посилення спонтанної агрегації тромбоцитів вже 
Показники агрегаційної активності тромбоцитів у осіб різного віку з ознаками МС за числом компонентів МС

\begin{tabular}{|c|c|c|c|c|c|}
\hline \multirow{3}{*}{ Показники } & \multirow{3}{*}{ Групи } & \multirow{2}{*}{\multicolumn{2}{|c|}{$\begin{array}{c}\text { 40-59 років } \\
\text { Кількість ознак MC }\end{array}$}} & \multirow{2}{*}{\multicolumn{2}{|c|}{$\begin{array}{c}60 \text { років і старше } \\
\text { Кількість ознак МС }\end{array}$}} \\
\hline & & & & & \\
\hline & & $1-2$ & $3-5$ & $1-2$ & $3-5$ \\
\hline \multirow{5}{*}{$\begin{array}{c}\text { В'язкість крові, сПз } \\
\text { при швидкостях } \\
\text { зсуву }\end{array}$} & $200 c^{-1}$ & $3,7 \pm 0,1$ & $4,0 \pm 0,2^{*}$ & $3,7 \pm 0,1$ & $3,6 \pm 0,1$ \\
\hline & $100 \mathrm{c}^{-1}$ & $3,9 \pm 0,1$ & $4,2 \pm 0,2^{*}$ & $3,9 \pm 0,1$ & $3,7 \pm 0,1$ \\
\hline & $50 \mathrm{c}^{-1}$ & $4,2 \pm 0,1$ & $4,4 \pm 0,1^{*}$ & $4,1 \pm 0,1$ & $4,0 \pm 0,1$ \\
\hline & $20 \mathrm{c}^{-1}$ & $4,5 \pm 0,1$ & $4,7 \pm 0,1^{*}$ & $4,4 \pm 0,1$ & $4,3 \pm 0,1$ \\
\hline & $10 \mathrm{c}^{-1}$ & $4,6 \pm 0,1$ & $4,8 \pm 0,2$ & $4,6 \pm 0,1$ & $4,4 \pm 0,1$ \\
\hline \multicolumn{2}{|c|}{ Індекс агрегації еритроцитів } & $1,14 \pm 0,02$ & $1,14 \pm 0,01$ & $1,15 \pm 0,01$ & $1,14 \pm 0,01$ \\
\hline \multicolumn{2}{|c|}{ Індекс деформованості еритроцитів } & $1,05 \pm 0,01$ & $1,05 \pm 0,01$ & $1,04 \pm 0,01$ & $1,04 \pm 0,01$ \\
\hline
\end{tabular}

\section{Примітки:}

Вірогідність різниці порівняно з групою 40-59 років з $1-2$ ознаками $\mathrm{MC}$ : ${ }^{\mathrm{p}}<0,05,{ }^{* *} \mathrm{p}<0,01$. Вірогідність різниці порівняно з групою 40-59 років з 3-5 ознаками $\mathrm{MC}$ : ${ }^{\mathrm{p}}<0,05,{ }^{\#} \mathrm{p}<0,01$. Вірогідність різниці порівняно з групою 60 років і старше з $1-2$ ознаками МC: ${ }^{a} \mathrm{p}<0,05$, ${ }^{\mathrm{aa}} \mathrm{p}<0,01$.

в середньому віці (таблиця 4). В групі людей похилого віку е тенденція до посилення спонтанної і АДФ-залежної агрегації тромбоцитів (таблиця 6). Це свідчить, про зростання тромбогенного потенціалу крові, що і сприяе процесу мікротромбоутворення задовго до маніфестації ЦД 2 типу. Це припущення підтверджено в літературі деякими авторами $[14,15]$.

Серед обстежених (таблиця 7) в'язкість крові зростае при збільшенні ознак МC у осіб середнього віку. Проте не виявлено статистично значимих відмінностей індексу деформованості еритроцитів між група- ми обстежених. Індекс агрегації еритроцитів теж не різнився між групами, але у людей похилого віку з «повним МС» цей показник зростав у більшій мірі (табл. 5).

Комплексний підхід до обстеження пацієнта та аналіз результатів дослідження показали, що, імовірно, зміни в системі мікроциркуляції та гемореологічних показників не лише довготривало існують не виявленими, як і самі ППВО, а й проходять певну «еволюцію» і стають основою для розвитку судинних ускладнень при розвитку ЦД 2 типу.

\section{ВИСНОВКИ}

1. При МС у осіб старше 60 років зменшуеться частка осіб із нормоглікемією і зростае частота виявлення поєднання порушення глікемії натще та порушення толерантності до глюкози.

2. Доцільно проведити СГТТ у осіб із ознаками МC (приховані порушення толерантності до глюкози при СГТТ виявляються у 15,3 \% осіб середнього віку та $39 \%$ осіб похилого віку) з метою виявлення ППВО.

3. Частота виявлення ППВО при "повному» $\mathrm{MC}$ практично однакова $(\mathrm{p}>0,05)$ у осіб середнього та похилого віку, проте структура ППВО різна: порушення глікемії натще в середньому $(p<0,01)$ і в похи- лому віці $(p<0,05)$ виявляеться частіше при «повному» $\mathrm{MC}$, порушення толерантності до глюкози $(p<0,05)$ та поєднання порушень - частіше $(\mathrm{p}<0,01)$ виявляеться у осіб старше 60 років навіть при наявності 1-2 ознак МС.

4. У людей старше 60 років з «повним МС» в капіляроскопічній картині наявні спазму артеріол та атонія венул, «сіткоподібна» розгалужена мережа капілярів із порушенням архітектоніки та зменшені кількості функціонуючих капілярів, збільшенням звивистості венул, уповільненням кровоплину з епізодами стазу і сладжфеномену та наявністю ліпідних відкла- 
день. В середньому віці з «повним МС» дані зміни відмічено на фоні практично збереженої архітектоніки судин із задовільною кількістю функціонуючих капілярів.

5. При «повному» МС при ППВО у осіб похилого віку відмічено зростання показ- ника спонтанної агрегації тромбоцитів, проте вираженіше зростання в'язкості крові відмічено у осіб середнього віку при практично однакових показниках індексів агрегації та деформованості.

\section{ЛITEPATУРА \\ (REFERENCES)}

1. Rodriguez-Colon SM, Mo J, Duan Y, et al. Stroke 2009; 40: 200-205.

2. Chen HJ, Bai CH, Yeh WT, et al. Stroke 2006; 37: 10601064.

3. Mi D, Jia Q, Zheng H, et al. PLoS One 2012; 7: e51406.

4. Callahan A, Amarenco P, Goldstein LB, et al. Arch Neurol 2011; 68: 1245-1251.

5. Liou CW, Tan TY, Lin TK, et al. Eur J Neurol 2008; 15: 802-809.

6. Weiqi Chen, Yuesong Pan, Jing Jingm et al. J Am Heart Assoc 2017; 6: e005446.

7. Expert Panel on Detection, Evaluation and Treatment of High Blood Cholesterol in Adults: Executive Summary of the Third Report of the National Cholesterol Education Program (NCEP) Expert Panel on Detection, Evaluation, and Treatment of High Blood Cholesterol in Adults (Adult Treatment Panel III). JAMA 2001; 285: 2486-2497.

8. Ryden L, Standl E, Bartnik M, et al. Eur Heart J 2007; 28(1): 88-136.

9. The Expert Committee on the Diagnosis and Classification of Diabetes Mellitus: Follow-up report on the diagnosis of diabetes mellitus. Diabetes Care 2003; 26 : 3160-3167.

10. American Diabetes Assosiation: Standards of Medical Care in Diabetes - 2016. Diabetes Care 2016; 39(1). doi: https://doi.org/10.2337/dc16-S003.

11. Malaja LT, Mikljaev IJu, Kravchun PG. Mikrocirkuljacija v kardiologii, Har'kov, 1977: 232 p.

12. Kozlov AA, Berkovskij AL, Kachalova ND, et al. Diagnosticheskie nabory i reagenty dlja gemoglobinometrii i issledovanija sistemy gemostaza: Sbornik instrukcij, Moskva, 2010: 96 p.

13. Moskalenko VF, Gulchiy OP, Colubchikov MV. Biostatistika, Kyiv, 2009: 184.

14. Noon JP, Walker BR, Webb DJ, et al. J Clin Invest 1997; 99: 1873-1879.

15. Jorneskog G, Kalani M, Kuhl J, et al. Diabetes Care 2005; 28: 1495-1497. 


\section{ОСОБЛИВОСТІ ЗМІН МІКРОЦИРКУЛЯТОРНОЇ ЛАНКИ СИСТЕМИ КРОВООБІГУ ПРИ МЕТАБОЛІЧНОМУ СИНДРОМІ В ЗАЛЕЖНОСТІ ВІД ПОЄДНАННЯ КІЛЬКОСТІ ЙОГО ОЗНАК У ОСІБ ПОХИЛОГО ВІКУ}

Коркушко О. В., Ніколаев Р. С., Шатило В. Б., Чижова В. П.,

Сафонова М. І., Самоць І. А., Дужак Г. В., Ковтонюк Т. I.

ДУ «Інститут геронтологї іл. Д. Ф. Чеботарьова НАМН Украӥни», м. Київ, Україна vchizhova@ukr.net

Дуже важливим для розуміння $е$ те, що кількість компонентів, що входять до складу метаболічного синдрому, це фрактори ризику серцево-судинних захворювань, прогресування попередніх захворювань серцево-судинної системи та змін системи мікроциркуляції. Відомо, що порушення толерантності до глюкози та порушення рівня глюкози натще є проміжними стадіями розвитку цукрового діабету. Ризик ранньої смерті від серцево-судинних захворювань у паціентів з проміжною стадією цукрового діабету в кілька разів вище, ніж у здорових людей. У той же час, механізми взаємного впливу метаболічного синдрому та предіабетичних розладів на особливості мікроциркуляції сьогодні недостатньо вивчені. Цей фркт і обумовив мету нашої роботи: зрозуміти роль предіабетичних порушень вуглеводного обміну при метаболічному синдромі в розвитку змін мікроциркуляції. 3 цією метою обстежено 142 людини різного віку. За ознакою поеднання компонентів метаболічного синдрому і предіабетичними розладами всіх паціентів поділили на різні групи. Найбільш виражені порушення метаболізму глюкози та мікроциркуляторної функції були виявлені у групи пацієнтів із поєднання $3-5$ симптомів (гіпертонія, переддіабет, ожиріння та дисліпідемія). Більшість пацієнтів були у віці 60 років і старше. Хворі цієї групи характеризувались суттєво вищим рівнемь глюкози та порушеннями мікроциркуляції. Негативний вплив на параметри мікроциркуляції та вищий ризик гіперкоагуляції відзначено у паціентів 40-59 років. Ці зміни мають ще виражені ший характер у літніх людей, які мають предіабетичні зміни. Формування переддіабету при метаболічному синдромі залежить від кількості компонентів метаболічного синдрому. Враховуючи наявність предіабетичних змін на фоні метаболічного синдрому, виявлені зміни мікроциркуляції можна розуміти як ранні прояви мікроангіопатії задовго до розвитку цукрового діабету та його загрозливих для життя судинних ускладнень.

Кл юч ові слова: метаболічний синдром, предіабетичні порушення вуглеводного обміну, мікроциркуляція, в’язкість крові, агрегаційна здатність тромбоцитів.

\section{THE FEATURES OF THE MICROCIRCULATION DISORDERS BY METABOLIC SYNDROME DEPENDING ON THE COMBINATION OF THE COMPONENTS IN THE ELDERLY}

Korkushko O. V., Nikolaiev R. S., Shatilo V. B., Chyzhova V. P., Safonova M. I., Samots I. A., Duzak G.V., Kovtonyuk T. I.

The State Institution "D. F. Chebotarev Institute of Gerontology NAMS Ukraine», Kiev, Ukraine vchizhova@ukr.net

How many components of the metabolic syndrome are very important to understanding about risk factors for cardiovascular disease and progression of previous diseases of the cardiovascular system and system of microcirculation. Impaired glucose tolerance and impaired fasting glucose form is intermediate stages in the natural history of diabetes mellitus. The risk of early death from cardiovascular diseases in patients with intermediate stages of diabetes mellitus in several times higher than risk in healthy people. At the same time, the mechanisms of mutual aggravated influence of metabolic syndrome and pre-diabetes disorders on the features of the microcirculation didn't sufficiently studied today. The aim of this study is to understanding what features of the microcirculatory disorders by metabolic syndrome is depended of different glucose level in the elderly. For this goal 142 people were examined. Due of the combination of components of the metabolic syndrome and pre-diabetes disorders all patients were divided into different groups. The most severe disorders of glucose metabolism and microcirculatory function were founded in group of patients with a combination of 3-5 symptoms (hypertension, pre-diabetes, obesity and dyslipidemia). The most of patients were in 60 age and over group. The patients of this group were characterized by significant higher glucose level and microcirculatory disorders. The negative effect on the microvessels parameters and risk of the hypercoagulation influence for pre-diabetes state were noted in patients 40-59 years old and more higher in elderly people. The negative effect on the microvessels parameters and higher risk of the hypercoagulation were noted in patients 40-59 years old and more higher in elderly people who have pre-diabetes status. The formation of pre-diabetes with metabolic syndrome is depends from their components. Given the presence of pre-diabetic changes in the background of the metabolic syndrome, the identified changes in microcirculation can be understood as early manifestations of microangiopathy long before the development of diabetes mellitus and its life-threatening vascular complications.

Key words: metabolic syndrome, pre-diabetes, microcirculation, blood viscosity, platelet aggregation. 